\title{
CYCADOPSIDA: HISTORY OF STUDY, VALUE, PERSPECTIVES OF USE
}

\author{
Gaidarzhy Olga, Ivannikov Roman*
}

M.M. Gryshko National Botanical Garden of the National Academy of Science of Ukraine, Kyiv, Ukraine

\section{САГОВНИКОВI (CYCADОРSIDA): ICTOРІЯ ВИВЧЕННЯ, ЗНАЧЕННЯ, ПЕРСПЕКТИВИ ВИКОРИСТАННЯ}

\section{Гайдаржи Ольга, Іванніков Роман}

\author{
Received: 08. 11. $2018 \quad$ Revised: 28. 11. $2018 \quad$ Published: 10. 12. 2018
}

\begin{abstract}
Representatives of Cycadopsida - a group of ancient plants, that appeared in the Permian period of the Paleozoic era. During the Jurassic and Triassic periods of the Mesozoic, they were an indispensable component of the plant communities until the appearance and distribution of representatives of Magnoliophyta. Today, 307 taxa of cycads are known. Plants of some species are traditionally used by the local population in everyday life, for food or in folk medicine. For various reasons, populations of most species are endangered. Some cycads species are no longer found in nature. All species of Ceratozamia, Chigua, Encephalartos and representatives of Cycas beddomei Dyer, Microcycas calocoma Miq. A. DC., Stangeria eriopus (Kunze) Baill are listed in I appendix CITES list. The remaining species of Cycadaceae are listed in appendix II. Most representatives of Cycadopsida are listed in the Red List of International Union for the Conservation of Nature and Natural Resources. Recent studies have shown the presence in valuable herbs of Cycadopsida of valuable, and sometimes, unique compounds and phytocomposition that can be used in pharmacy and cosmetology. In the work, the scientific, practical and historical significance of the Cycadopsida is formulated, the traditional methods of their use and perspectives of study are indicated. Taking into account the main directions of scientific and educational work carried out in the NBG M.M. Gryshko National Academy of Sciences of Ukraine, with the collection of Cycadopsida, provides information on the history of the discovery and study of the representatives of this group of ancient gymnosperms. In the context of the formation of the modern taxonomic hierarchy of the Cycadopsida mentioned the most prominent scientists who were engaged in descriptions and study of this group of plants.
\end{abstract}

Keywords: Cycadopsida, Cycas, Zamia, gymnosperms

*Corresponding author: Ivannikov Roman, M.M. Gryshko National Botanical Garden of the National Academy of Science of Ukraine, Timiriazevska st. 1, Kyiv 01014, Ukraine $\triangle$ namor.iv22@gmail.com 
Стійкість екологічних систем зокрема і біосфери в цілому значною мірою залежить від біологічного різноманіття. Зменшення різноманітності біоти - найбільш небезпечна серед змін довкілля, що відбуваються нині, бо це абсолютно незворотній процес. Зникнення в ході філогенезу окремих видів є частиною процесу еволюційного розвитку, проте, їм на заміну мають приходити нові види. Сьогодні, через споживацьке ставлення до природи (пряме чи опосередковане), через потужний вплив людини на природу цей процес критично порушено. Достатнє видове різноманіття, з одного боку, забезпечує гомеостатичний стан біогеоценозів, 3 іншого, для людини, при раціональному використанні, це невичерпне джерело природних ресурсів.

Саговники - це група унікальних, давніх рослин, які з'явилися вже в пермському періоді палеозойської ери. Вони панували в часи юрського та тріасового періодів мезозою i лише з появою та розповсюдженням представників Magnoliophyta, їх чисельність та різноманіття суттєво зменшились. До теперішнього часу описано 307 таксонів саговикових (IUSN, 2018). Сучасні представники саговникових широко розповсюджені в усьому світі (рис. 1), хоча основна частина видів (до 70\%) походить з Китаю, В`єтнаму (рис. 2), Австралії, Південної Африки та Мексики (рис. 1). Близько 25\% всіх видів класу знаходяться під загрозою зникнення, а 15\% - вважаються вразливими внаслідок втрати середовища існування та неконтрольованого використання (Yang et al., 2017).

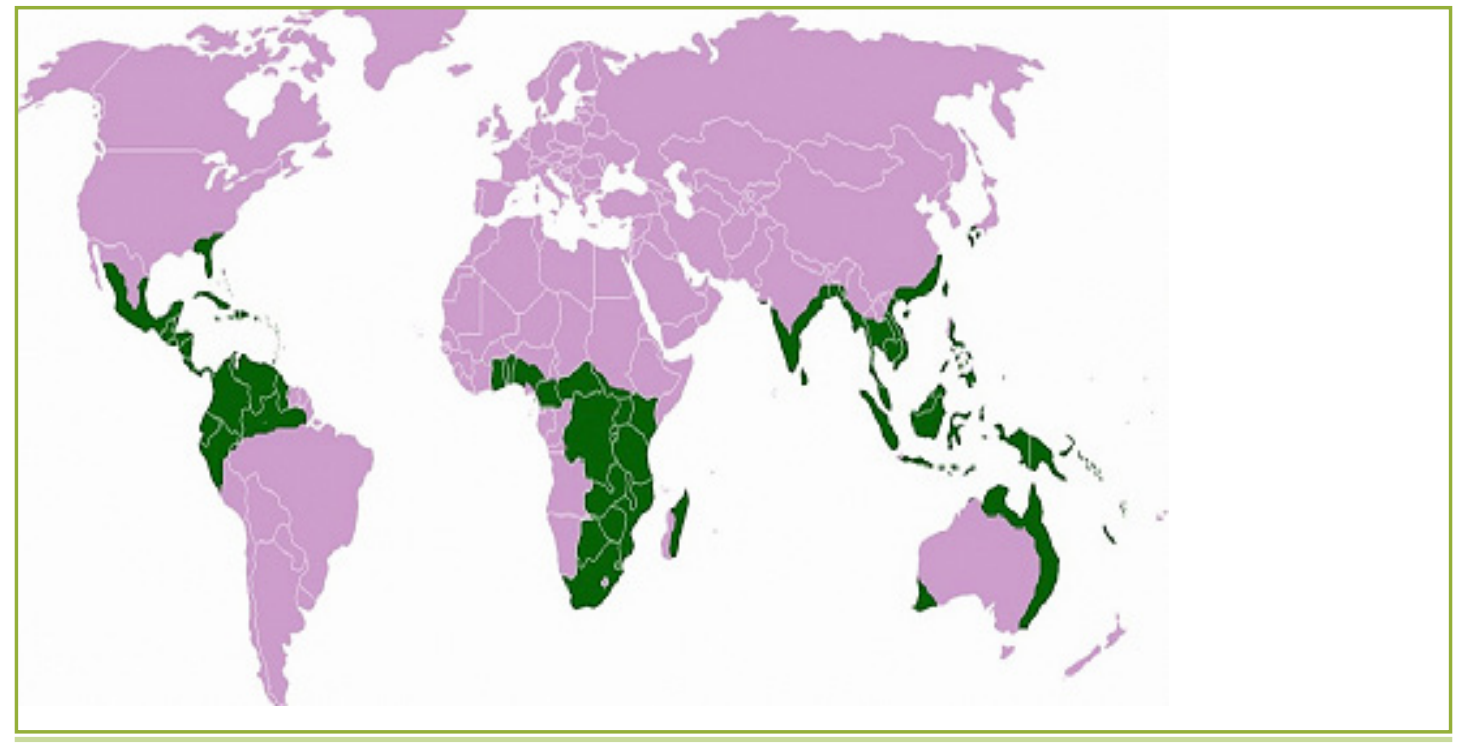

Рисунок 1 Розповсюдження представників Сусаdopsida

Figure 1 Distribution of representatives of Cycadopsida

Деякі види саговникових відомі лише завдяки декільком екземплярам, що залишились в природі. Всі види родів Ceratozamia Brongn., Chigua D.W.Stev., Encephalartos Lehm. і представники Cycas beddomei Dyer, Microcycas calocoma Miq. A. DC., Stangeria eriopus (Kunze) Baill занесені у Додаток I списку CITEC (CITES, 1973). Інші види родини Сусаdaceae Pers. внесені у Додаток II. Більшість представників цієї групи рослин 
занесені у Червоний Список Міжнародного Союзу Охорони Природи і Природних ресурсів - МСOП (IUSN, 2018).

Саговникові - рідкісні рослини, в ботанічних садах України представлені зазвичай поодинокими екземплярами та тривіальними видами. Найбільші колекції утримуються в оранжереях Національного ботанічного саду ім. М.М. Гришка, у ботанічному саду ім. акад. О.В. Фоміна Київського Національного університету ім. Тараса Шевченка, ботанічному саду Львівського університету ім. І.Я. Франка та ботанічному саду Харківського Національного університету ім. В. Н. Каразіна.

У Європі не існує місць природного зростання саговникових, хоча до нас дійшли згадки про те, як більше чотирьох тисяч років тому давні етруски знайшли дивну скам'янілість (стовбур одного 3 представників Cycadopsida) (Wieland, 1916). Незвичні на вигляд рештки рослини, імовірно, привернули увагу, і вони встановили скам'янілий стовбур у некрополі Марзаботто (нині муніципалітет в Італії, у регіоні Емілія-Романья). Цей викопний екземпляр є зразком, з якого було описано Cycadeoidea etrusca Capellini \& Solms. Його рештки і сьогодні знаходяться в Музеї Каппелі в Болоньї.

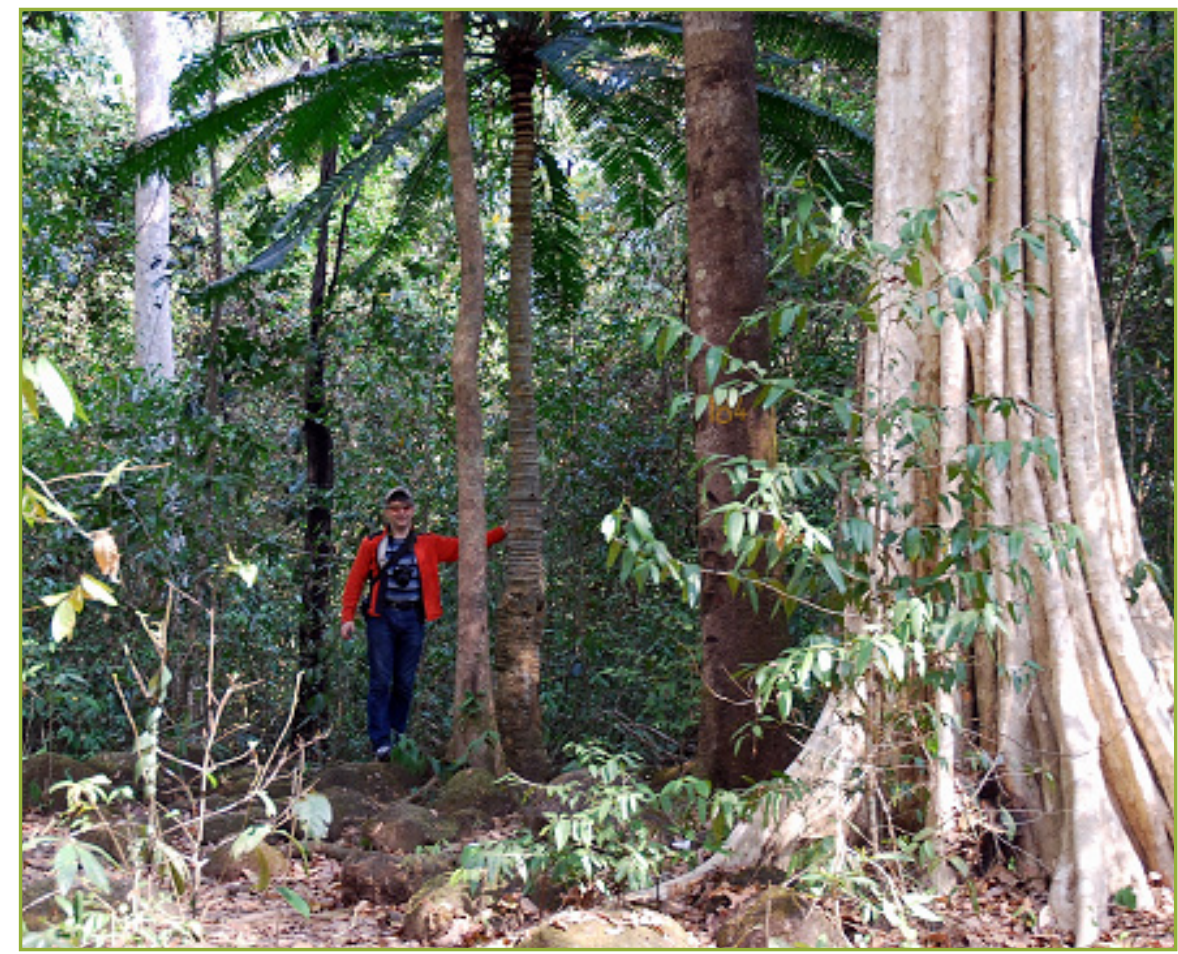

Рисунок 2 Південний В’єтнам, заповідник. Cycas spp. в місцях природного зростання, 2014 p. Figure 2 South Vietnam, nature reserve. Cucas spp. in places of natural habitats, 2014

В місцях природного зростання Cycadopsida традиційно широко використовуються місцевим населенням у господарстві (в харчуванні, в народній медицині, для виготовлення різних побутових виробів, у садівництві і т.д.). В Азії їх застосовують для 
прикрашання садів, низькорослі представники видів, що походять із Південного Китаю та Північного В`єтнаму популярні як рослини в стилі бонсай. У китайській та японських культурах саговники високо цінують як символи довголіття, про що свідчить широке застосування народної назви “Фен Вей Цао” (“трава-хвіст фенікса”) або “Фен Вей Джао” ("пальма-хвіст фенікса"), як натяк на міфічного фенікса, легендарну істоту, що "відроджується з полум'я його похоронного багаття".

Як джерело харчових продуктів, саговникові застосовували з прадавніх часів в Індії, Південно-східній Азії, Японії, Австралії і інших країнах. Згадки про рослини цієї групи зустрічаються з IX століття. В записах двох арабських натуралістів йдеться про те, що здавна рослини роду Cycas L. використовували як джерело борошна в Iндії.

Європейці вперше познайомилися з представниками цієї групи голонасінних ще y XIII ст., коли венеціанський купець Марко Поло привіз на батьківщину саго крохмалевмісний продукт, що отримують зі стовбура саговникових. Існують записи про те, що пізніше, у XVIII ст., учасники експедиції Дж. Кука познайомилися зі звичаєм вживанням в їжу аборигенами Австралії насіння саговників (Miquel, 1842, 1862). Пізніше, у XVI столітті, А. Пігафетта, Ф. Кастанеда і Ф. Дрейк знайшли рослини Cycas на Молуккських островах (інд. Kepulauan Maluku), де, маючи інформацію про їх їстівні властивості, спробували їх вживати їжу.

3 початком масштабного освоєння Нового Світу багато мандрівників-натуралістів робили у своїх щоденниках нотатки та рисунки цих незвичних рослин, повідомляли про відкриття нових видів. Живі саговники регулярно завозили в ботанічні сади та створювали гербарії.

Одні із перших нотаток про саговникові в Новому Світі були зроблені Дж. Леріо. У своїй подорожі до Бразилії, у 1576 році, він спостерігав використання рослин, які корінне населення називало “айрієм“. Рослини цієї групи тепер відносять до роду Zamia L. Одними з перших натуралістів які зібрали цінний матеріал під час своїх досліджень у тропічній Америці були А. Гумбольдт і Е. Бонплан (1799-1804). Пізніше, Ф. Поепіг в 1830-х роках, повідомляв про збори зразків саговникових в Перу та Болівії.

Серед приватних колекцій відділялось свого часу зібрання англійця Дж. Етіса. Він був ботаніком-аматором, вивчав саговникові, спілкувався з багатьма вченимиботаніками того часу. Його гербарій було пожертвувано Британському музею в Лондоні. Також в літературі (Osborne et al., 2006) згадується Ф. Гарбарі, лікар з Тренто (північ Італії), колекцію якого успадкував ботанічний сад Флоренції в 1907 році. Л. Каліфано, всесвітньо відомий патологоанатом, а також відомий колекціонер саговникових, заповів свою колекцію Неапольському ботанічному саду (1976 р.).

Особливий інтерес з ботанічної точки зору викликає робота датського дослідника Ф. Лібманна, який у 1840 році в Мексиці збирав матеріали для опису представників Dioon Lindl. та Ceratozamia Brongn. (Wendland, 1854). Водночас, В. Карвінскій, у 18411843 рр. очолював експедицію до Південної Америки, організовану Петербурзькою Академією наук. Певний час він досліджував флору Мексики. Після його подорожі до ботанічного саду в м. Санкт-Петербург було привезено живий матеріал, на 
прикладі якого було описано новий вид, назва якого не зберіглась. Впродовж XIX століття надходили данні від мандрівників-натуралістів про нові види, що знаходили в Південній Америці - у цей період було зібрано багато рослинного матеріалу як для ботанічних садів, так і для приватних колекцій.

Перший ботанічний опис рослини, що належить до порядку Cycadales, був здійснений ботаніком Х. Драакестейном, який описав саговникові під назвою Todda-panna у 1682 році. Згодом, К. Ліней, у 1753 році, використовуючи ілюстрації цього ботаніка, назвав рід Cусаs (Linneaus, 1753).

Перші серйозні кроки у систематиці саговникових зробив Ф. Мікаель, голландський ботанік. Його робота (видана у 1842 р.) є прикладом наукової строгості та якості корисної інформації. У 1861 році він опублікував свої дописи за назвою: "Prodromus Systematis Cycadearum”, в яких оприлюднив всю відому на той час інформацію з біології та систематики цих рослин. Ще одна вичерпна за інформацією монографія була видана 1868 році де Кандолем (de Candolle) “Сусаdaceae. Prodromus systematis naturalis”. He менш важливою, з нашого погляду, є робота директора ботанічного саду у СанктПетербурзі Регеля (Regel, 1857) “Сусаdearum generum specierumque revisio”.

Тільки наприкінці XIX сторіччя роботи німецького ботаніка В. Гофмейстера разом з роботами японських ботаніків С. Хіразе та С. Ікено визначили місце саговникових серед вищих рослин як однієї з найдревніших груп голонасінних. Перші ботанічні описи родів Cycas і Zamia, як зазначалося, були зроблені К. Лінеєм у 1753 році. Пізніше стало відомо, що під родовою назвою “Cycas” К. Лінней описував як мінімум три різних види, які відомі і на сьогодні. Серед його записів частіше за все згадувався Cycas circinalis L., проте з восьми екземплярів, які були використані при описах К. Лінеєм лише два належать виду C. circinalis. Інші екземпляри, як стало відомо пізніше, належать видам Cycas revoluta Thunb., 1784, та Cycas rumphii Miq.,1839.

У 1842 році Ф. Мікаель описав австралійський рід Macrozamia Miq., в наступному році Д. Ліндлі описав новий північноамериканський рід, який він назвав Dioon. Пізніше $(1861,1868,1870)$ цим автором було опубліковано низку досліджень по саговниковим, серед яких була робота під назвою “Nouveaux materiaux pour servir a la connaissance des Cycadees”, в якій було оприлюднено всі відомі на той час знання з систематики та біології цих рослин. Рід Zamia вперше описав К. Лінней у 1763 (Linneaus, 1763).

Саговникові, що належать до роду Encephalartos Lehm., вперше описані Й. Леманном в 1834 році. Назва роду походить від грецьких слів “en”, що означає "в”, “cephale”, що означає "голова" і “artos”, що означає "хліб”. За свідченнями автора, туземне населення отримувало муку з насіння верхньої частини стробілів рослин цього роду (Lehmann, 1834). За два роки, у 1846 р. А. Бронгніарт описав рід, який він назвав Ceratozamia Brongn.(з гр. «хеras» - «ріг»), щоб підкреслити своєрідну будову спорофілів (Brongniart, 1846).

У 1853 році Т. Мур описав невеликий південноафриканський рід, який він назвав Stangeria T. Moore на честь доктора Стангера, генерального начальника Натальської провінції, який в 1851 році відіслав з ним рослину в Англію з порту Натал (Moore, 
1853). Вперше вид Stangeria eriopus (Kunze) Baill. описав О. Кунце в 1892 році. Першочергово цей вид було ідентифіковано як папороть роду Lomaria и тільки потім, беручи до уваги роботи Мура по опису стробілів, цей вид систематизували як той, що відноситься до порядку Cycadales (Vorster, 1985).

У 1857 році Е. Регель описав новий австралійскій рід, якому він дав назву Lepidozamia Lehm., додаючи до назви Zamia грецьку назву (“lepis” = шкала), тому що листкові рубці на стовбурі цієї рослини нагадують луску змії (Regel, 1857). Пізніше, у 1863 році, Дж. Хукер описав новий австралійський рід Bowenia Hook. f., на честь ботаніка і першого губернатора Квінсленда сера Дж. Ф. Боуена. Де Каудолле описав рід Microcycas (Miq.) A. DC. - ендем з о. Куба, додавши слово "micro" до назви Cycas, хоча це не зовсім коректно, оскільки за розмірами екземпляри Microcyas бувають більші, ніж рослини Cycas (Caudolle, 1868).

Одним із найвідоміших дослідників саговникових був американський ботанік К. Дж. Чемберліан, чиї праці викликали інтерес завдяки великій кількості наукових даних та новизні його підходу до вивчення предмету. Впродовж 15 років він подорожував Африкою, Америкою та Австралією, спостерігаючи саговникові в їх природному середовищі, що дало поштовх до написання у 1919 році монографічного зведення “The living cycads". Це інформативна та цікава монографія, яка і на сьогодні залишається актуальною стосовно таксономії, морфології та репродуктивної біології саговникових; більшість наведеної інформації отримано автором внаслідок проведення оригінальних досліджень (Chamberlain, 1919).

На початку 1940-х років К. Дж. Чемберлен написав ще одну монографію, присвячену рослинам порядка Cycadales, в якій він повідомив про певні неточності попередніх досліджень цієї групи. Приміром, він рішуче критикує практику описання нових видів з єдиного зразка гербарію або живої рослини сумнівного походження, без розуміння мінливості цих рослин протягом їх життєвого циклу. На жаль, ця робота ніколи не була опублікована. Копії рукопису Чемберлена зберігаються в Тропічному саду Ферріхільда в Майямі, Нью-Йоркському ботанічному саду та Ботанічному саду Неаполя (Chamberlain, 1943; Haynes, 2007).

Систематика цієї групи голонасінних впорядковується і донині. Майже половина визнаних на сьогодні день видів саговникових були таксономічно ідентифіковані в останні 20 років. Так, нові таксони саговників були описані і в останні десятиліття, зокрема, Д. Стівенсон і К. Ностог описали новий, ендемічний, розповсюджений на дуже обмеженій території східної частині Південної Америки рід роду Cycas - C. chigua (Stevenson, 1990).

Як було зазначено, за останніми офіційними даними на сьогодні відомо 307 видів саговникових, які відносяться до 11 родів. Сучасні рослини цієї групи розповсюджені в усіх частинах світу, крім Європи та Антарктиди. Станом на 2018 р. загальноприйняте систематичне зведення саговникових є результатом обє єнаної роботи Д. Хендрікса, К. Хілла, Р. Осборна та Д. Стівенсона, які працювали над ним упродовж останніх двох десятиліть. У коментарях до нього автори зазначають: “Наш перший “Світовий 
список" був опублікований в "Encephalartos, Journal of the Cycad Society of South Africa" з незначними змінами в додатковому списку в наступному випуску того ж журналу. Кілька оновлень слідували за новими відкриттями та змінами в таксономії та в світогляді, особливо в родах Cycas, Encephalartos, Macrozamia і Zamia, що зробили попередні списки застарілими. Вони були представлені на різних міжнародних конференціях присвячених питанням біології саговникових" (Hill et al., 2004).

Широке використання представників Cycadopsida у народній медицині завжди наводило на думку проте, що ці рослини містять цінні, фізіологічно активні сполуки. Від початку, хімічні дослідження саговникових зосередилися на виділенні та ідентифікації токсичних складових. Перші дослідження були здійснені в Австралії наприкінці IXX ст. Вони були спрямовані на виділення та вивчення таких речовин як смоли, муцин і щавлева кислота. У 1900 роках голландський уряд в Ост-Індії на численні прохання щодо вивчення шкідливих компонентів насіння C. circinalis, що був джерелом харчового крохмалю на островах, започаткував його дослідження. Робота була здійснена в Голландії, було виділено “аморфний безазотистий глікозид", який було названо пакоеін. Пізніше проводились дослідження C. revoluta та Macrozamia spiralis (Salisb.) Miq., насіння яких було визнано отруйними (Whitelock, 2002).

Друга світова війна перервала дослідження саговникових, але відразу після війни вони були відновлені. У 1949 і 1951 рр., Б. Ланглей, Н. Ріггс, та Б. Лісгое, які працювали з австралійськими видами, виділили глікозид макрозамін. Пізніше він був виділений з Cycas, Bowenia та Encephalartos. У 1956 році Н. Ріггс отримав схожі, але не ідентичні речовини з насіння C. circinalis (Whiting, 1963).

Крім глікозидів у саговникових було виділено декілька інших сполук. К. Нішіда i М. Йошиміра виділили на ідентифікували інозитом з насіння C. revoluta. У 1949 році, працюючи з Macrozamia riedlei (Gaudich.) Ч. Гарднер, Е. Ріггс описали виділення та ідентифікацію сек'юітолу (sequoyitol), простого моноетилового ефіру мезо-інозиту. Одна з причин цікавості до вивчення сек'юітолу в тому, що він міститься у мозку і нервовій тканині.

Пошуки інших токсинів, крім циказіну, у саговникових увінчались успіхом у 1967 році, коли було виділено і описано $\beta$-метил-L-аланін (BMAA), доведено, що ця сполука продукується ціанобактеріями, що вступають у симбіотичні відносини з коренями деяких саговникових (Vega et al., 1967). У 1967 амінокислота $\beta$-метил-L-аланін (BMAA) була виділена з рослин - представників Cycas. Нейротоксична активність цього

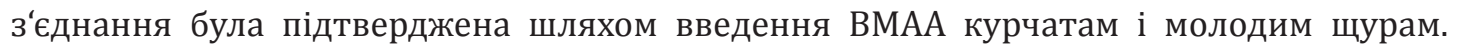
Згідно досліджень, тільки L-ізомер цієї сполуки проявляє токсичні ефекти (Vega et al., 1968). Встановлено, що ВМАА міститься в насінні саговникових. В результаті подальших досліджень було доведено, що цез'єднання відповідає за високий рівень захворюваності в Гуамі у місцевого населення БАС (боковий аміотрофічний склероз). Хоча, відомо, що при традиційному вживанні тієї кількості ВМАA, яка надходить в організм не достатньо, щоб викликати неврологічне ушкодження. Проте було висловлено припущення, що BMAA може біологічно посилюватись шляхом біологічного ланцюга. При подальших 
дослідженнях ВМАА було встановлено, що сильний токсичний вплив на мозок можливий лише при дуже високих концентраціях. Епідеміологічні дані людини та вивчення тварин в природних умовах показують, що кількість ВМАА, що надходить до організму з мукою, яку отримують при переробці саговникових, не достатньо, щоб викликати нейродегенеративне захворювання.

Упродовж останніх десятиліть широко вивчались антибактеріальні властивості саговникових, зокрема досліджувалась наявність алкалоїдів, сапоніни і вуглеводи у насінні Cycas circinalis (Kalpashree et al., 2013; Moawadetal, 2013). Саркотеста, склеротеста та ендотеста були досліджені на антибактеріальну активність проти трьох патогенних бактерій, зокрема Bacillus cereus, Staphylococcus aureus, Escherichia coli. Порівняння інгібуючих активність екстрактів 3 антибіотиками ванкоміцин і пеніцилін проти людських патогенних бактерій показало, що екстракт метанолу 3 насіння Cycas circinalis був більш дієвим, ніж у протестованих антибіотиків. Дослідження показали, що листя Cycas revoluta також володіють потужною антимікробною і антиоксидантною діями (Bissa et al., 2008). Також було досліджено пептид Ala-Trp-Lys-Leu-Phe-Asp-Asp-Gly-Val, що отримали насіння Cycas revoluta за допомогою обернено-фазової рідинної хроматографії. Цей пептид демонструє шкідливий вплив проти людського епідермоїдного раку і ракових клітин товстої кишки (НСТ15). Пептид викликає гальмування проліферації ракових клітин i подальшого руйнування нуклеосомної структури, індукції апоптозу шляхом прямого зв'язування ДНК (Mandal, 2012). Апоптоз був виявлений в гістологічних зрізах тканини мозку і кишечника дорослих мишей, яких годували препаратами 3 насіння Lepidozamia peroffskyana. Ця форма клітинної смерті була також знайдена на високих рівнях в мозковій тканині мишей, народжених від дорослих мишей, яких годували препаратом (Gobe, 1994).

Результати досліджень Cycas beddomei показали наявність 23 фенольних сполук, 7 флавоноїдів і 5 антоціанідінових з'єднань у всіх частинах рослини. Ці сполуки $\epsilon$ біологічно активними в якості антимікробних проти патогенних бактерій людини, що викликають шкірні захворювання, ревматизм і виразки (Alekhya et al., 2013).

Нами було досліджено листя представників Ceratozamia kuesteriana Regel, Ceratozamia robusta Mig., Cycas circinalis L., Cycas micholitzii Dyer, Cycas revoluta Thunb., Cycas rumphii Mig., Zamia integrifolia L.f., Zamia loddigesii Mig., Zamia pumila L.. Роботи проводились з рослинами колекцій Національного ботанічного саду ім. М.М. Гришка НАН України та ботанічного саду ім. акад. О.В. Фоміна КНУ ім. Тараса Шевченка. В результаті проведених досліджень було виявлено, що найбільш токсичними за вмістом азаглакозидів є Ceratozamia kuesteriana Regel, Zamia loddigesii Mig. та Cycas circinalis L. не менш важливими є результати порівняльного біохімічний аналізу, що виявив незначні відмінності у різностатевих представників окремих видів (Грахов та ін., 2015; Гайдаржи та ін., 2018).

В останні десятиліття спостерігається все більший інтерес до біосистематики, порівняльної морфології, екології, фізіології та репродуктивної біології саговникових, 
зокрема, не можна не згадати про професора К. Норстога, лідера у вивченні репродуктивної біології цієї групи (Norstog et al., 1997).

Свідоцтва токсичності саговникових надходять з багатьох джерел. На жаль, клінічні і лабораторні данні щодо захворювань, пов'язаних зі споживанням саговникових в їжу, майже відсутні. Експерименти показали, що глікозиди призводять до пошкодження печінки, але немає доказів, що споживання будь-яких компонентів рослин можуть призвести до паралічу.

\section{Висновки}

Таким чином, беручи до уваги літературні дані та отримані результати власних досліджень, можна стверджувати, що представники класу Cycadales є цінними джерелами біологічно активних сполук, та потребують подальшого, більш глибоко вивчення. Відкритими є питання щодо статевої ідентифікації представників цієї групи рослин, які ще не досягли репродуктивного віку, розмноження, ex situ та in vitro, раціонального використання та збереження in situ. Важливим є вивчення рослин в умовах ex situ з метою встановлення динаміки росту і розвитку рослин впродовж тривалого часу для формулювання оптимальних агротехнічних заходів з метою успішного утримання колекцій у ботанічних закладах та вивчення перспектив інтродукції. Нині більшість саговникових знаходяться під загрозою вимирання, оскільки вони походять з місць, які активно експлуатуються людиною. Деякі види відомі лише за кількома особинами. Однак, через інтерес до їх хімічного складу, декоративних властивостей, багато саговникових знайшли притулок у державних та приватних садах по всьому світу, проводяться роботи щодо збереження зникаючих видів, триває селекція.

\section{Література}

ГАЙДАРЖИ, О., ГРАХОВ, В., ІВАННІКОВ, Р. 2018. Дослідження складу вторинних метаболітів рослин Cусаdopsida колекції НБС НАНУ В мат. міжн. наук.-практ. конф. до 100-річчя НАН України: Фундаментальні та прикладні аспекти інтродукції рослин у реаліях євроінтеграції. Київ: - Ліра-К, с. 188. ISBN 978-617-7605-82-8.

ГРАХОВ, В., ГАЙДАРЖИ, О., ІВАННІКОВ, Р., БОЙКО, О. 2015. Характеристика якісного та напівкількісного складу компонентів листків ряду саговникових Cycadopsida ex situ В мат. : міжн. наук. конф.: Інтродукція рослин, збереження та збагачення біорізноманіття в ботанічнихсадахтадендропарках. Київ: Фитосоциоцентр, с. 59-60.ISBN 978-966-306-185-2.

ALEKHYA, C., YASODAMMA, N., CHAITHRA, D. 2013. Qualitative analysis of phenols, flavonoids and anthocyanidins of Cycas beddomei Dyer. An endemic gymnosperm of seshachalam hill ranges. In Indo American Journal of Pharmaceutical Research, vol. 3(1), p. 1632-1641. Available at: https:// www.ejmanager.com/mnstemps/36/36-1393405456.pdf

BISSA S., BOHRA, A. 2008. Antibacterial potential of three naked seeded (gymnosperm) plants. In Natural Product Radiance, vol. 7(5), p. 420-425. Available at: https://pdfs.semanticscholar. org/19db/89cabcea18aeb57346b969e2cbd43f606c53.pdf

CAUDOLLE, A. 1868. Cycadaceae. In Prodromus sys tematis naturalis, vol. 16(2), p. 522-548.

CHAMBERLAIN, C.J. 1919. The living cycads. University of Chicago Press, Chicago. 
IUSN 2004. 2004 IUSN Red List of Threatened Species. www.redlist.org Downloaded on 7 March 2018.

GOBE, G.C. 1994. Apoptosis in Brain and Gut Tissue of Mice Fed a Seed Preparation of the Cycad Lepidozamia peroffskyana. In Biochemical and Biophysical Research Communications, vol. 205(1), p. 327-333. http://dx.doi.org/10.1006/bbrc.1994.2668

HILL, K.D., STEVENSON, D.W., OSBORNE, R. 2004. The world list of cycads. Proceedings of the Fifth International Conference on Cycad Biology (CYCAD 99). In Botanical Review, 70, p. 274-298. http:// cycadconservation.org/publications/Haynes-Historical-Review-of-World-List-of-Cycads-2008.pdf

KALPASHREE, M.M., RAVEESHA, K.A. 2013. Antibacterial Activity of Cycas circinalis Ovules - A Naked Seeded Gymnosperm. In International Journal of Herbal Medicine, vol. 1(3), p. 53-55. Available at: http://www.florajournal.com/archives/2013/vol1issue3/PartA/19.1.pdf

LEHMANN, J.G.C. 1834. Novarum et minus cognitarum stirpium pugillus sextus. Meissner, Hamburg, p. 1-66. http://dx.doi.org/10.5962/bhl.title.45011

WHITELOCK, L.M. 2002. The cycads. Hardcover; Portland, Oregon, U.s.a.: Timber Press, Incorporated. ISBN 0881925225.

WHITING, M.G. 1963. Toxicity of Cycads. In Economic Botany, vol. 17(4), p. 270-302.

MIQUEL, F.A. W. 1842. Monographia cycadearum. Utrecht.

MIQUEL, F.A. W. 1861. Prodromus systematis cycadearum. C. v. D. Post Amsterdam. C. G. v. D. Post. Jr., Utrecht.

MOAWAD, A., HETTA, M., ZJAWIONY, J.K., JACOB, M.R., HIFNAWY, M., MARAIS, J.P., FERREIRA, D. 2010. Phytochemical investigation of Cycas circinalis and Cycas revoluta leaflets: moderately active antibacterial biflavonoids. In Planta Med., vol. 76(8), p. 796-802. http://dx.doi. org/10.1055/s-0029-1240743

MOORE, T. 1853. List of Mr. Plant's Natal ferns. Hooker's. In J. Bot. Kew Gard. Misc., vol. 5, p. 228-229.

NORSTOG, K.J., NICHOLLS, T.J. 1997. The biology of the cycads. Cornell University Press, Ithaca, New York, USA.

OSBORNE, R., STEVENSON, D.W.M., VOVIDES, A.P. 2006. What is Ceratozamia fuscoviridis? In Delpinoa, vol. (48), p. 5-10.

REGEL, E. 1857. Zwei neue Cycadeen. In Bull. Soc. Imp. Naturalistes Moscou, vol. (30), p. 163-191.

MANDAL, S.M., MIGLIOLO, L., DAS, S., MANDAL, M., FRANCO, O.L., HAZRA, T.K. 2012. Identification and characterization of a bactericidal and proapoptotic peptide from Cycas revoluta seeds with DNA binding properties. In J. Cell Biochem., vol. 113(1), p. 184-93. http://dx.doi.org/10.1002/jcb.23343

STEVENSON, D.W. 1990. Chigua, a new genus in the Zamiaceae with comments on its biogeographic significance. In Mem. New York Bot. Gard., vol. 57, p. 169-172.

WIELAND, G. 1916. American fossil cycads. Vol. II. Taxonomy. Carnegie Institution of Washington. 